УАК: 658.477

\section{ПРОГНОЗУВАННЯ ДИНАМІКИ ПОТОЧНИХ ЛОГІСТИЧНИХ МАТЕРІАЛЬНИХ ВИТРАТ СІЛЬСЬКОГО ГОСПОААРСТВА УКРАЇНИ ${ }^{\odot}$}

Н.А. ПОТАПОВА, кандидат економічних наук, доцент, доцент кафедри комп'ютерних наук та економічної кібернетики, Вінницький національний аграрний університет (м. Вінниця)

Досліджується проблематика прогнозування поточних логістичних матеріальних витрат сільського господарства України. Встановлено особливості класифікаиії логістичних витрат та їх відповідність бухгалтерському обліку, на підставі чого формується їх місие при оціниі ефективності логістичної системи. Однією із основних складових поточних логістичних витрат сільськогосподарських підприємств визначено матеріальні витрати, щео обтрунтовує необхідність їх прогнозування при плануванні показників логістичної діяльності.

Тенденції змін поточних логістичних матеріальних витрат досліджуються за допомогою часових трендів як по сільськогосподарських підприємствах, так і в розрізі напрямів діяльності рослинництва та тваринництвва. На основі апроксимованої функції експоненціального росту поточних логістичних матеріальних витрат визначено прогноз даного показника в п'ятирічній перспективі. Надано характеристики достовірності та якості моделей прогнозування, які підтверджують можливість для їхнього використання при розробиі логістичних стратегій сільськогосподарських підприємств.

Ключові слова: поточні логістичні витрати, матеріальні витрати, прогнозування, прогностична функція, якість прогнозу.

Рис. 3, Табл. 4, Літ. 15

\title{
FORECASTING THE DYNAMICS OF CURRENT LOGISTICS MATERIAL COSTS OF AGRICULTURE IN UKRAINE
}

\author{
Nadiya POTAPOVA, \\ candidate of economic sciences, associate professor, \\ associate professor of computer science \\ and economic cybernetics department, \\ Vinnytsia National Agrarian University, \\ Vinnytsia
}

The problem of forecasting the current logistics material costs of agriculture in Ukraine is investigated. The features of the classification of logistics costs and their compliance with accounting are established, on the basis of which their place is formed in assessing the effectiveness of the logistics system. One of the main components of the current logistics costs of agricultural enterprises identified material costs, which justifies the need to predict them when planning indicators of logistics activities.

Trends in the current logistics material costs are investigated using time trends in the aggregate for agricultural enterprises, and in the context of activities of crop and livestock. On the basis of the approximated function of exponential growth of the current logistic material expenses the forecast of this indicator in the five-year prospect is defined. The characteristics of reliability and quality of forecasting models, which confirm the possibility of their use in the development of logistics strategies of agricultural enterprises, are given.

Key words: current logistics costs, material costs, forecasting, prognostic function, forecast quality.

Fig. 3, Tabl. 4, Lit. 15

ПРОГНОЗИРОВАНИЕ ДИНАМИКИ ТЕКУЩИХ ЛОГИСТИЧЕСКИХ МАТЕРИАЛЬНЫХ ИЗДЕРЖЕК СЕЛЬСКОГО ХОЗЯЙСТВА УКРАИНЫ 


\section{5 \\ http://efm.vsau.org/ \\ Н. А. ПОТАПОВА, \\ кандидат экономических наук, доцент, доцент кафедры компьютерных наук \\ и экономической кибернетики, \\ Винницкий национальный аграрный университет,}

2. Винница

Исследуется проблематика прогнозирования текучих логистических материальных издержек сельского хозяйства Украины. Определены особенности классификаиии логистических издержек и их соответствие бухгалтерскому учету, на основании чего формируется их место при оченке эффективности логистической системы. Одной из основных составляющих текущих логистических издержек сельскохозяйственных предприятий определены материальные, что обосновывает необходимость их прогнозирования при планировании показателей логистической деятельности.

Тенденции изменений текущих логистических материальных издержек исследуются $c$ помощью временных трендов. Они рассматриваются в иелом по сельскохозяйственным предприятиям, а также в разрезе направлений деятельности растениеводства и животноводства. На основе аппроксимированной функиии экспоненциального роста текущих логистических материальных издержек определен прогноз данного показателя в пятилетней перспективе. Даны характеристики достоверности и качества моделей прогнозирования, которые подтверждают возможность их использования при разработке логистических стратегий сельскохозяйственных предприятий.

Ключевые слова: текущие логистические издержки, материальные издержки, прогнозирование, прогностическая функция, качество прогноза.

Рис. 3, Табл. 4, Лит. 15

Постановка проблеми. Ефективність логістики на підприємствах різних форм власності визначена синергетичними складовими, що виникають у результаті поєднання процесів постачання, виробництва та збуту в єдиний ланцюг управління. Даний процес відображується в зміні характеристик запасів, обслуговуванні замовлень, тривалості операційного циклу та ін. Логістичний підхід в управлінні поєднаний перш за все з елементами оптимізації повних витрат, розмір яких впливає на кінцевий результат діяльності підприємства.

За думкою експертів витрати на логістику на українських підприємствах становлять щорічно близько \$10 млрд. У відсотках до ВВП логістичні витрати в країнах світу складають від 6 до $26 \%$, зокрема: Японія - $6 \%$, СС - 12\%, Україна - 15\%, США - $16 \%$, Китай - $26 \%$.[1]

Високий рівень логістичних витрат зумовлює проблематику їх оцінювання, класифікації, планування та прогнозування. Виникають проблеми при співвідношенні логістичних витрат зі стандартами бухгалтерського обліку основних видів витрат та джерел їх утворення. Логістичні витрати входять складовою в сукупні операційні витрати і можуть бути виділені відносно елементів логістичних процесів.

Аналіз останніх досліджень та публікацій. Відсутність єдиного підходу в класифікації та складових елементах логістичних витрат, а також їх роль в оцінці ефективності логістичних систем зумовлюють необхідність досліджень 3 даного напряму. Науковцями досліджується влив логістичних витрат на сукупні характеристики логістичних систем, особливості їх формування та адаптація до стандартів обліку, розроблено теоретичні засади щодо їх визначання та ін. Аналіз досліджень Кузнецової Т.В. [1], Крикавського Є.В. [3], Васелевського М. [3], Якимишин Л.Я. [4], Сумця О.М. [4] та ін. дозволили зробити висновок, про неоднозначність у формулюванні поняття логістичних витрат та методичних підходів щодо їх оцінювання в системі логістичного менеджменту. Зокрема, залишаються невирішеними питання щодо побудови та оцінювання прогнозів логістичних витрат, визначення їх місця в управлінні логістикою, а також прикладних аспектів особливостей формування логістичних витрат галузей та секторів економіки.

Формулювання цілей статті. Метою статті $є$ визначення та оцінювання прогнозу поточних логістичних матеріальних витрат сільського господарства України.

Виклад основного матеріалу. Стратегічне управління економічними об'єктами передбачає діï, направлені на досягнення основних цілей: максимізацію прибутків або мінімізацію витрат. Управління витратами є ключовим питанням з позиції ефективності функціонування підприємства. Саме в цій частині, передбачається прийняття рішень по формуванню витрат, їх плануванню та прогнозуванню на найближчу перспективу, а також функції контролю та моніторингу. 
http://efm.vsau.org/

В умовах глобалізаційних змін зростає вплив логістичних чинників на фінансові показники підприємств, який обгрунтовується наступним [3]:

- частка логістичних витрат при реалізації продукції продажу зростає за умови зростання віддаленості ринків, що несе в собі складову витрат на доставку (транспорт та комунікації);

- густина товару при пакуванні (або розміщенні) впливає на частку логістичних витрат в обсязі реалізації продукції (складські приміщення завантажуються більш оптимально товарами 3 великою густиною, чим забезпечують відсутність пустих місць).

- відношення вартості до об’єму товарів впливає на планування транспортних та складських витрат в логістиці

- ступінь ризику товарів впливає на зростання частки логістичних витрат в обсязі реалізації логістичних витрат в обороті.

Вплив логістичних витрат відображується на обсязі реалізації, що вимагає від підприємців забезпечити контроль за зміною вартості по всьому ланцюгу постачання. Злагоджене функціонування всіх ділянок логістичного ланцюга мінімізує ризики конфліктів, що породжуються в ньому завдяки цільовій різнонаправленості [3].

Реакція на зміни обсягів витрат та регулювання даного процесу несе в собі корегування бюджету, а разом з цим і ризики щодо повноти його виконання. В основу концепції формування логістичних витрат покладено концепцію загальних витрат Г. Льюиса, Дж. Каллитона і Дж. Стіла [4], зміст якої полягає в можливості інтеграції логістичних операцій для групування певних видів та класів витрат з метою зниження сукупної вартості продукту при його постачанні від виробника до кінцевого споживача. Концепція висвітлює співвідношення між окремими видами витрат та можливістю їх перегрупування відносно логістичних операцій, що має на меті отримання кінцевого зниження витрат по усьому логістичному ланцюгу.

Витрати в логістиці є категорією, що визначає сутність самого логістичного управління, оскільки, його направленість пов'язана 3 оптимізацією витрат на усьому шляху проходження продукту (від виробника до кінцевого споживача). Слід зазначити, що в логістиці факт виникнення витрат відбувається в ланцюзі постачання на кожній ділянці, через яку проходить матеріальний потік. При досягненні кінцевого споживача, виникають повні реалізаційні витрати, сформовані по ключових складових вартості ресурсів, їх обслуговування та сервіс, транспортування, складування, націнка посередників та ін. Таким чином, коли ми говоримо про логістичні витрати, ми маємо розуміти природу їх релевантності та джерело виникнення у відповідності до логістичних активностей [5].

При аналізі категорії “логістичні витрати” більшість авторів ототожнюють їх класифікацію відносно логістичних активностей (операцій) та логістичної діяльності підприємства. Складнощі у визнанні даного виду витрат полягають у виділені логістичних операцій діяльності підприємства в єдиний логістичний ланцюг по усьому бізнес-процесу. 3 позиції технології виробництва більшість логістичних витрат $€$ складовою операційних витрат та включаються у повну собівартість продукції, залежно від способу їх нарахування. Проте, на кожній просторовій ділянці логістичного ланцюга виникають витрати, обумовлені логістичними активностями і рухом логістичного потоку. Таким чином, при управлінні логістичними витратами керуються основними принципами $[3,8]$ :

- системність при побудові механізму управлення логістичними витратами;

- визнання єдиної методики по оцінці та управління витратами на різних рівнях ієрархії управління;

- побудова ланцюга управлення логістичними витратами у межах логістичного циклу існування продукту (життєвий цикл продукту);

- використання методів та моделей мінімізації витрат;

- контролінг витрат на всіх стадіях та місцях їх виникнення в логістичному ланцюзі;

- моніторинг витрат в ключових точках логістичного потоку.

Забезпечити виконання даних принципів на підприємстві можливо завдяки побудові “гнучкої логістики”, здатної побудувати систему прийняття рішень з швидким адаптаційним механізмом постачань, закупівель, дистрибуції та ін. В межах цілісного логістичного ланцюга існує проблема визнання логістичних витрат стосовно місця їх утворення (відносно складових ланцюга), а також їх віднесення до елементів затрат згідно ресурсної складової [9].

В межах стандартів бухгалтерського обліку України виділення окремих статей логістичних витрат ускладнюється і може бути вирішеним при формуванні системи управлінського обліку підприємства. Логістичний ланцюг проектується в межах моделі бюджетування підприємства 3 


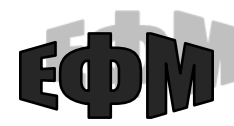

http://efm.vsau.org/

виділенням центрів витрат по відношенню до центрів логістичних функцій підприємства та класифікатору управлінських логістичних витрат. Регулювання відхилень відбуватиметься через корегування управлінської звітності. Складовою узгодженості логістичних витрат з класифікацією облікових процесів за чинним законодавством України може бути поділ на капітальні й поточні логістичні витрати [6]. Логістичні витрати співвідносяться до видів активів, що забезпечують процес обігу ресурсів (грошових та матеріальних). Сільськогосподарське виробництво залежить від використання біологічних активів, життєвий цикл яких обумовлений біологічними законами, які мають специфічні ознаки як у тваринництві (процес вирощування тварин), так і у рослинництві (процес вирощування насаджень). Визначення виробничої собівартості враховує витрати в межах тривалості повного циклу виробництва готової продукції. Сезонність виробництва обумовлює витрати на управління запасами (формування, утримання та ін.), які у відповідності до бухгалтерської класифікації $є$ матеріальними витратами і становлять найбільшу питому вагу в повній собівартості. Таким чином, формування логістичних витрат має відбуватись у межах системи управлінського обліку на засадах концепції загальних витрат підприємства, яка включає складові:

- потокову бізнес-модель бюджетування логістичної системи підприємства;

- аналітичний класифікатор логістичних операцій в межах логістичної системи підприємства та ланцюгів постачання конкретних продуктів та видів послуг;

- правила віднесення логістичних витрат до відповідного класу (аналітичної групи) логістичних операцій;

- визначення прогнозу та часового терміну віднесення логістичних витрат.

3 позиції оптимізації повних витрат та логістичної ефективності матеріальні витрати будуть класифікуватись як поточні логістичні матеріальні витрати на конкретний вид продукту. При управлінні поточними логістичними витратами матеріальні витрати є основним елементом планування та прогнозування логістичної діяльності.

Оцінка змін тенденцій економічних факторів може проводитись на основі моделей прогнозування, отриманих із використанням відповідних економіко-математичних методів. Одним із таких підходів $\epsilon$ апроксимація функції за методом найменших квадратів $[11,12]$. Критерієм оптимізації даного методу є дотримання умов мінімізації суми квадратів відхилень значень фактору фактично отриманих та теоретично оцінених. В такий спосіб, за отриманим рядом ретроспективних даних встановлюють форму залежності функції, яку у подальшому оцінюють на основі методу найменших квадратів з високим рівнем достовірності. Рівняння часового тренду має загальний вигляд функції:

$$
\mathrm{y}_{\text {пр }}=\mathrm{f}(\mathrm{t})
$$

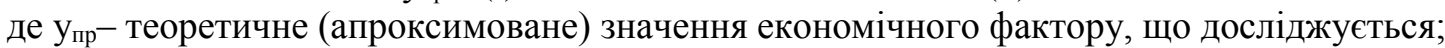

$\mathrm{f}(\mathrm{t})$ - функція часових змін даного фактору;

$\mathrm{t}-$ фактор часу.

Визначення виду функції проводиться у відповідності до фактичних значень досліджуваного показника і мінімізації відхилень між цими значеннями та теоретично оціненими по моделі. Основними характеристиками функції прогнозу є іiі направленість відносно процесу зростання (зростаюча або спадаюча), характеристика лінійності функції (лінійна або крива зростання), відповідність параметрів критеріям значимості моделі. В більшості випадків аналіз економічних процесів оцінюється на основі нелінійних функцій $[13,14]$, до основних ознак яких можна віднести нерівномірність часових приростів та наявність нестійких станів рівноваги в часі. При економетричному аналізі таких процесів форми залежностей описують нелінійними функціями, які у подальшому лінеарізують 3 метою можливого використання лінійних оцінок. Така методика дозволяє провести економетричний аналіз процесів на основі лінійних коефіцієнтів оцінки тісноти зв'язку та значимості параметрів.

Методика оцінки значимості моделі і параметрів включає проведення дисперсійного аналізу 3 використанням статистичного F-критерію Фішера при заданому рівні значимості $(\alpha)$ та ступенях вільності $\left(\mathrm{f}_{\mathrm{i}}\right)$. Оцінка гіпотези про адекватність моделі базується на порівнянні Грозр (розрахункове значення критерію Фішера) з Ғтабл (табличне значення критерію Фішера). Модель $є$ адекватною у випадку Fрозр $\geq$ Fтабл, при Fрозр<Ғтабл - модель не адекватна.

Прогнозна оцінка може коливатись у межах довірчих інтервалів змін параметрів моделі, тобто описуватиметься верхнім та нижнім порогом значень. Оцінка значимості параметрів моделі проводиться 3 використанням статистичного t-критерію Ст'юдента. Якість прогнозу може оцінювати на основі середньої відносної та абсолютної похибки. 
http://efm.vsau.org/

У відповідності до обраної методики на основі ретроспективного ряду даних поточних логістичних матеріальних витрат в сільському господарстві України за період 2008 - 2017 рр. отримано загальний вид рівняння прогнозу:

$$
\mathrm{y}_{\text {пр }}=\mathrm{b}_{0} \mathrm{e}^{\mathrm{blt}}
$$

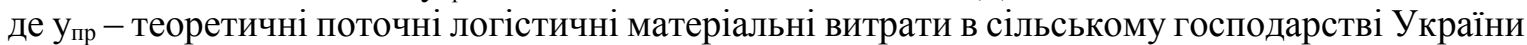
оцінені за методом найменших квадратів, млн. грн.;

$\mathrm{t}-$ фактор часу;

$\mathrm{b}_{0}, \mathrm{~b}_{1}-$ коефіцієнти рівняння, отримані за методом найменших квадратів.

За методом найменших квадратів визначено коефіцієнти і оцінене рівняння функції прогнозу поточних логістичних матеріальних витрат в сільському господарстві України, яке має вигляд:

$$
\mathrm{y}_{\text {пр сг }}=30064,76 \mathrm{e}^{0,1973 \mathrm{t}}
$$

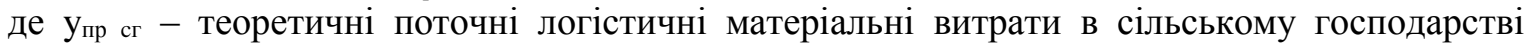
України оцінені за МНК, млн. грн.

$\mathrm{t}-$ фактор часу.

Результати розрахунків прогнозованих значень поточних логістичних матеріальних витрат в сільському господарстві України на 2008 - 2022 рр. наведено у таблиці 1. Лінійний коефіцієнт кореляції оцінки зв'язку даної моделі 0,994, що свідчить про високу щільність зв'язку між факторами за даним видом моделі. Коефіцієнт детермінації дорівнює 0,988, що підтверджує високий рівень апроксимації функції часових змін показника обраним типом залежності.

Порівняння розрахункового та табличного значень критерію Фішера, дозволило зробити висновок щодо підтвердження адекватності моделі, $\mathrm{F}_{\text {розр }} \geq \mathrm{F}_{\text {таб̆л }}(\alpha=0,05, \mathrm{fl}=1, \mathrm{f} 2=8)$, тобто $666,54 \geq 5,32$. Оцінка параметрів моделі за t-критерієм Ст'юдента встановила, що коефіцієнти моделі $\epsilon$ значимими $\left(\mathrm{t}_{\text {розр }} \geq \mathrm{t}_{\text {табл }}(\alpha=0,05, \mathrm{f}=8)\right)$, зокрема:

- $\quad b_{0}$ : Значимий, $t_{\text {розр }} \geq t_{\text {табл }}, 217,45 \geq 2,31 ;$

- $\quad b_{1}$ : значимий, $t_{\text {розр }} \geq t_{\text {таб̆ }}, 25,82 \geq 2,31$.

Таблиия 1

Результати розрахунків прогнозованих значень поточних логістичних матеріальних витрат

\begin{tabular}{|c|c|c|c|}
\hline Рік & $\begin{array}{c}\text { Фактичні поточні } \\
\text { логістичні матеріальні } \\
\text { витрати в сільському } \\
\text { господарстві України, } \\
\text { млн. грн. (у) }\end{array}$ & $\begin{array}{c}\text { Теоретичні поточні логістичні } \\
\text { матеріальні витрати в } \\
\text { сільському господарстві } \\
\text { України оцінені за МНК, млн. } \\
\text { грн. (Упр сг) }\end{array}$ & $\begin{array}{c}\text { Відхилення } \\
\text { теоретичного від } \\
\text { фактичного } \\
\text { значення, \% }\end{array}$ \\
\hline 2008 & 38980,7 & 36622,3 & 6,1 \\
\hline 2009 & 42405,9 & 44610,1 & $-5,2$ \\
\hline 2010 & 52528,2 & 54340,2 & $-3,4$ \\
\hline 2011 & 70732,2 & 66192,5 & 6,4 \\
\hline 2012 & 84855,7 & 80630,0 & 5,0 \\
\hline 2013 & 88541,7 & 98216,5 & $-10,9$ \\
\hline 2014 & 108700,9 & 119638,8 & $-10,1$ \\
\hline 2015 & 153108,9 & 145733,6 & 4,8 \\
\hline 2016 & 183175,5 & 177520,1 & 3,1 \\
\hline 2017 & 221405,2 & 216239,6 & 2,3 \\
\hline 2018 & $*$ & 263404,4 & $*$ \\
\hline 2019 & * & 320856,5 & * \\
\hline 2020 & * & 390839,6 & * \\
\hline 2021 & $*$ & 476087,0 & $*$ \\
\hline 2022 & $*$ & 579928,0 & $*$ \\
\hline Сума & 1044435,0 & 1039743,7 & $-2,0$ \\
\hline $\begin{array}{l}\text { Середнє } \\
\text { значення }\end{array}$ & 104443,5 & 103974,4 & $-0,2$ \\
\hline
\end{tabular}
в сільському господарстві України, 2008 - 2022 рр.

Джерело: складено та розраховано автором на основі [ 13]

Нижня і верхня межа коефіцієнтів моделі прогнозу при рівні довірчої імовірності 0,95 по показнику за період 2008 - 2022 рр. мають значення: $26950,60 \leq b 0 \leq 33538,77 ; 0,17 \leq b 1 \leq 0,21$. Часові зміни поточних логістичних матеріальних витрат в сільському господарстві України мають 


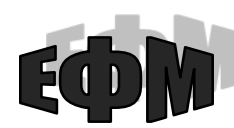

http://efm.vsau.org/

низький рівень еластичності і характеризуються середнім зростанням на $0,197 \%$ щорічно. Очікуваний розмір поточних логістичних матеріальних витрат в сільському господарстві на період 2018 - 2020 рр. коливається у межах від 263404,4 до 579928,0 млн. грн. Середній рівень відхилень теоретичних від фактичних значень становить -0,2\%. При цьому абсолютна похибка прогнозу 5,7\%.

Діапазон коливань прогнозованих значень поточних логістичних матеріальних витрат в сільському господарстві України у межах 95\% довірчих інтервалів показано на рисунку 1.

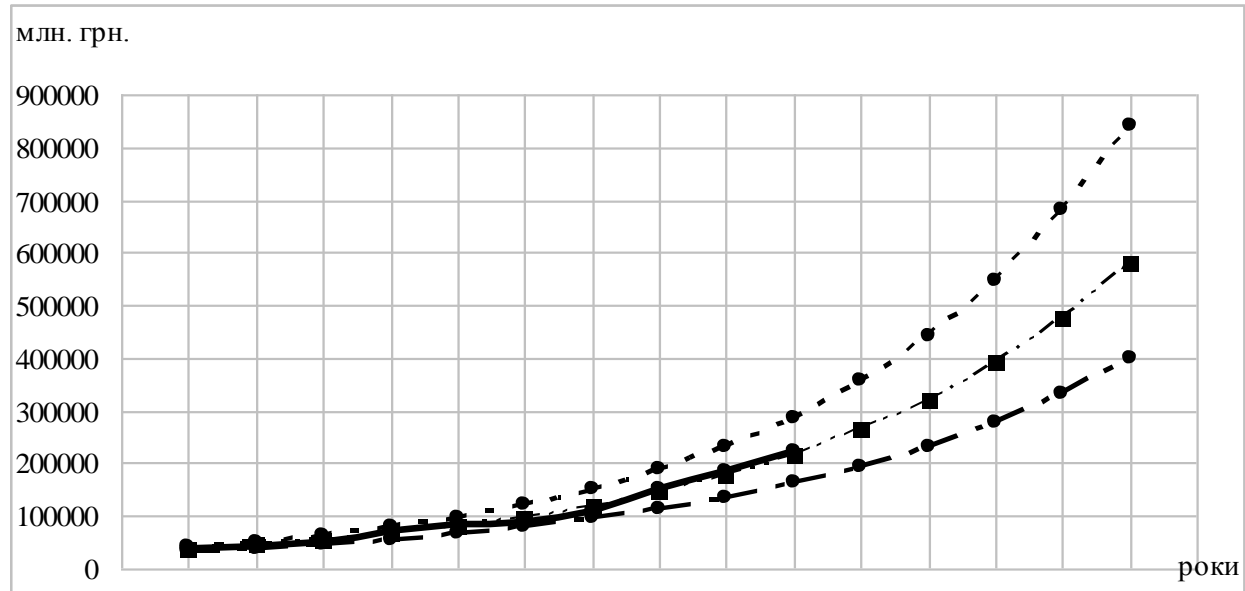

20072008200920102011201220132014201520162017201820192020202120222023

ـ Фактичні поточні логістичні матеріальні витрати в сільському господарстві України, млн. грн.

- - - Теоретичні поточні логістичні матеріальні витрати в сільському господарстві України оцінені за МНК, млн. грн.

- • - Нижній діапазон прогнозу

- -•- - Верхній діапазон прогнозу

Рис. 1. Прогнозування поточних логістичних матеріальних витрат в сільському господарстві України, 2008 - 2022 рр., млн. грн.

Джерело: розроблено автором за даними [13]

Результати розрахунків прогнозованих значень поточних логістичних матеріальних витрат в рослинництві України на 2008 - 2022 рр. наведено у таблиці 2. За методом найменших квадратів визначено коефіцієнти і оцінене рівняння функції прогнозу поточних логістичних матеріальних витрат в рослинництві України, яке має вигляд:

$$
\mathrm{y}_{\text {пр росл }}=19276,83 \mathrm{e}^{0,2066 \mathrm{t}}
$$

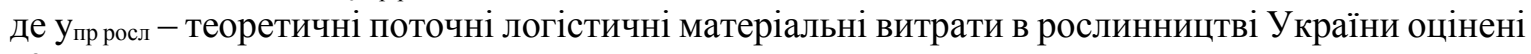
за МНК, млн. грн.

$\mathrm{t}-$ фактор часу.

Лінійний коефіцієнт кореляції оцінки зв'язку даної моделі 0,991, що свідчить про високу щільність зв'язку між факторами за даним видом моделі. Коефіцієнт детермінації дорівнює 0,982 , що підтверджує високий рівень апроксимації функції часових змін показника обраним типом залежності. Порівняння розрахункового та табличного значень критерію Фішера, дозволило зробити висновок щодо підтвердження адекватності моделі, $\mathrm{F}_{\text {розр }} \geq \mathrm{F}_{\text {табл }}(\alpha=0,05, \mathrm{fl}=1, \mathrm{f} 2=8)$, тобто $439,22 \geq 5,32$. Оцінка параметрів моделі за t-критерієм Ст'юдента встановила, що коефіцієнти моделі $\epsilon$ значимими $\left(\mathrm{t}_{\text {розр }} \geq \mathrm{t}_{\text {табл }}(\alpha=0,05, \mathrm{f}=8)\right)$, зокрема:

- $\mathrm{b}_{0}$ : значимий, $\mathrm{t}_{\text {розр }} \geq \mathrm{t}_{\text {табл, }}, 161,28 \geq 2,31$;

- $\mathrm{b}_{1}$ : значимий, $\mathrm{t}_{\text {розр }} \geq \mathrm{t}_{\text {табл }}, 20,96 \geq 2,31$.

Часові зміни поточних логістичних матеріальних витрат в рослинництві мають низький рівень еластичності і характеризуються збільшенням на 0,207\% щорічно. Очікуваний розмір поточних логістичних матеріальних витрат в рослинництві на період 2018 - 2020 рр. коливається у межах від 187130,0 до 427653,2 млн. грн. Середній рівень відхилень теоретичних від фактичних значень становить - $0,3 \%$. При цьому абсолютна похибка прогнозу 7,9\%. 
http://efm.vsau.org/

Таблиия 2

Результати розрахунків прогнозованих значень поточних логістичних матеріальних витрат в рослинництві України, 2008 - 2022 рр.

\begin{tabular}{|c|c|c|c|}
\hline Рік & $\begin{array}{c}\text { Фактичні поточні } \\
\text { логістичні матеріальні } \\
\text { витрати в рослинництві } \\
\text { України, млн. грн. (у) }\end{array}$ & $\begin{array}{c}\text { Теоретичні поточні логістичні } \\
\text { матеріальні витрати в } \\
\text { рослинництві У країни оцінені за } \\
\text { МНК, млн. грн. (Упр росл) }\end{array}$ & $\begin{array}{l}\text { Відхилення } \\
\text { фактичного від } \\
\text { теоретичного } \\
\text { значення, \% } \\
\end{array}$ \\
\hline 2008 & 25621,4 & 23701,3 & 7,5 \\
\hline 2009 & 26574,5 & 29141,4 & $-9,7$ \\
\hline 2010 & 33118,2 & 35830,0 & $-8,2$ \\
\hline 2011 & 48210,8 & 44053,9 & 8,6 \\
\hline 2012 & 58359,2 & 54165,3 & 7,2 \\
\hline 2013 & 60402,6 & 66597,5 & $-10,3$ \\
\hline 2014 & 77282,1 & 81883,3 & $-6,0$ \\
\hline 2015 & 109486,0 & 100677,4 & 8,0 \\
\hline 2016 & 132745,2 & 123785,4 & 6,7 \\
\hline 2017 & 141904,2 & 152197,1 & $-7,3$ \\
\hline 2018 & $*$ & 187130,0 & $*$ \\
\hline 2019 & $*$ & 230080,9 & $*$ \\
\hline 2020 & $*$ & 282890,0 & $*$ \\
\hline 2021 & $*$ & 347820,1 & $*$ \\
\hline 2022 & $*$ & 427653,2 & $*$ \\
\hline Сума & 713704,1 & 712032,5 & $-3,2$ \\
\hline $\begin{array}{l}\text { Середнє } \\
\text { значення }\end{array}$ & 71370,4 & 71203,2 & $-0,3$ \\
\hline
\end{tabular}

Джерело: складено та розраховано автором на основі [13]

Діапазон коливань прогнозованих значень поточних логістичних матеріальних витрат в рослинництві України у межах 95\% довірчих інтервалів показано на рисунку 2.

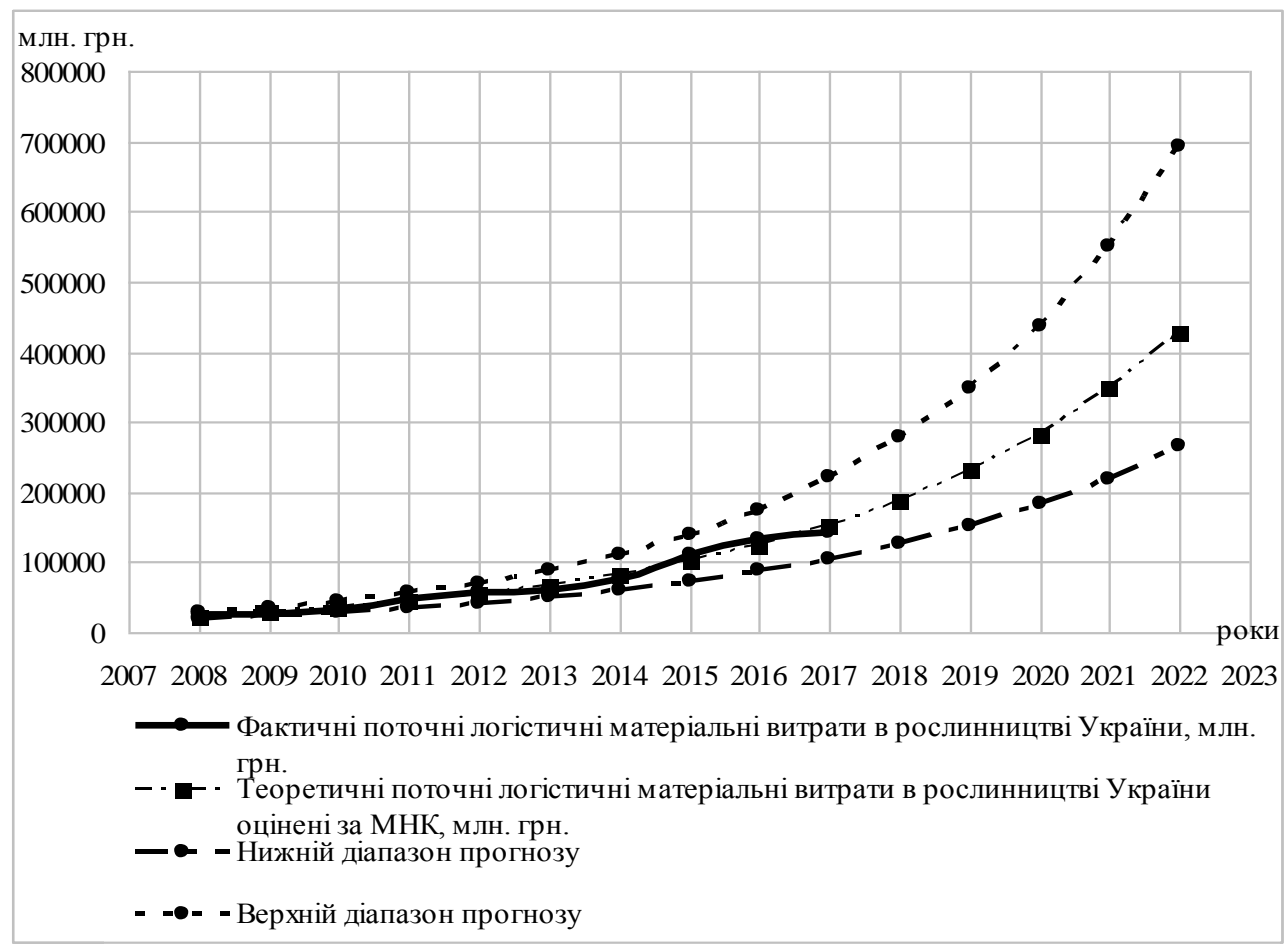

Рuc. 2. Прогнозування поточних логістичних матеріальних витрат в рослинництві України, 2008 - 2022 рр., млн. грн.

Джерело: розроблено автором за даними [13] 


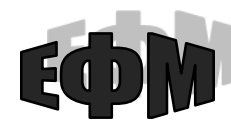

http://efm.vsau.org/

Результати розрахунків прогнозованих значень поточних логістичних матеріальних витрат в тваринництві України на 2008 - 2022 рр. наведено у таблиці 3.

Таблиця 3

Результати розрахунків прогнозованих значень поточних логістичних матеріальних витрат в тваринництві України, 2008 - 2022 рр.

\begin{tabular}{|c|c|c|c|}
\hline Рік & $\begin{array}{c}\text { Фактичні поточні логістичні } \\
\text { матеріальні витрати в } \\
\text { тваринництві України, млн. } \\
\text { грн. (у) }\end{array}$ & $\begin{array}{c}\text { Теоретичні поточні логістичні } \\
\text { матеріальні витрати в } \\
\text { тваринництві України оцінені } \\
\text { за МНК, млн. грн. ( } \hat{y})\end{array}$ & $\begin{array}{c}\text { Відхилення } \\
\text { фактичного } \\
\text { від } \\
\text { теоретичного } \\
\text { значення, \% }\end{array}$ \\
\hline 2008 & 13359,3 & 12916,7 & 3,3 \\
\hline 2009 & 15831,4 & 15423,9 & 2,6 \\
\hline 2010 & 19410,1 & 18417,7 & 5,1 \\
\hline 2011 & 22521,4 & 21992,6 & 2,3 \\
\hline 2012 & 26496,5 & 26261,4 & 0,9 \\
\hline 2013 & 28139,1 & 31358,9 & $-11,4$ \\
\hline 2014 & 31418,8 & 37445,7 & $-19,2$ \\
\hline 2015 & 43622,9 & 44713,9 & $-2,5$ \\
\hline 2016 & 50430,3 & 53393,0 & $-5,9$ \\
\hline 2017 & 79501,0 & 63756,7 & 19,8 \\
\hline 2018 & $*$ & 76132,0 & $*$ \\
\hline 2019 & $*$ & 90909,4 & $*$ \\
\hline 2020 & $*$ & 108555,1 & $*$ \\
\hline 2021 & $*$ & 129625,9 & $*$ \\
\hline 2022 & $*$ & 154786,5 & $*$ \\
\hline Сума & 330730,8 & 325680,6 & $-5,0$ \\
\hline $\begin{array}{c}\text { Середнє } \\
\text { значення }\end{array}$ & 33073,1 & 32568,1 & $-0,5$ \\
\hline
\end{tabular}

Джерело: складено та розраховано автором на основі [13]

За методом найменших квадратів визначено коефіцієнти і оцінене рівняння функції прогнозу поточних логістичних матеріальних витрат в тваринництві України, яке має вигляд:

$$
\mathrm{У}_{\text {пр твар }}=10817,12 \mathrm{e}^{0,1774 \mathrm{t}}
$$

де $\hat{\mathrm{y}}$ - теоретичні поточні логістичні матеріальні витрати в тваринництві України оцінені за МНК, млн. грн.

t- фактор часу.Лінійний коефіцієнт кореляції оцінки зв'язку даної моделі 0,981, що свідчить про високу щільність зв'язку між факторами за даним видом моделі. Діапазон коливань прогнозованих значень поточних логістичних матеріальних витрат в тваринництві України у межах 95\% довірчих інтервалів показано на рисунку 3. Коефіцієнт детермінації дорівнює 0,963 , що підтверджує високий рівень апроксимації функції часових змін поточних логістичних матеріальних витрат в тваринництві України обраним типом залежності. Порівняння розрахункового та табличного значень критерію

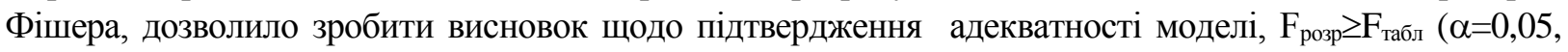
$\mathrm{fl}=1, \mathrm{f} 2=8$ ), тобто 207,03 $\geq 5,32$. Оцінка параметрів моделі за t-критерієм Ст'юдента встановила, що коефіцієнти моделі $є$ значимими ( $\left.\mathrm{t}_{\text {розр }} \geq \mathrm{t}_{\text {табл }}(\alpha=0,05, \mathrm{f}=8)\right)$, зокрема:

- $\mathrm{b}_{0}$ : значимий, $\mathrm{t}_{\text {розр }} \geq \mathrm{t}_{\text {табл, }}, 121,43 \geq 2,31$;

- $\mathrm{b}_{1}$ : значимий, $\mathrm{t}_{\text {розр }} \geq \mathrm{t}_{\text {таблл }}, 14,39 \geq 2,31$.

Нижня і верхня межа коефіцієнтів моделі прогнозу при рівні довірчої імовірності 0,95 поточних логістичних матеріальних витрат в тваринництві України за період $2008-2022$ рр. мають значення: $9067,75 \leq b 0 \leq 12903,97 ; 0,15 \leq b 1 \leq 0,20$. Часові зміни поточних логістичних матеріальних витрат в тваринництві України мають низький рівень еластичності і характеризуються середнім збільшенням на $0,177 \%$ щорічно. Очікуваний розмір поточних логістичних матеріальних витрат в тваринництві на період 2018 - 2020 рр. коливається у межах від 76132,0 до 154786,5 млн. грн. Середній рівень відхилень теоретичних від фактичних значень становить -0,5\%. При цьому абсолютна похибка прогнозу становить 7,3\%. 


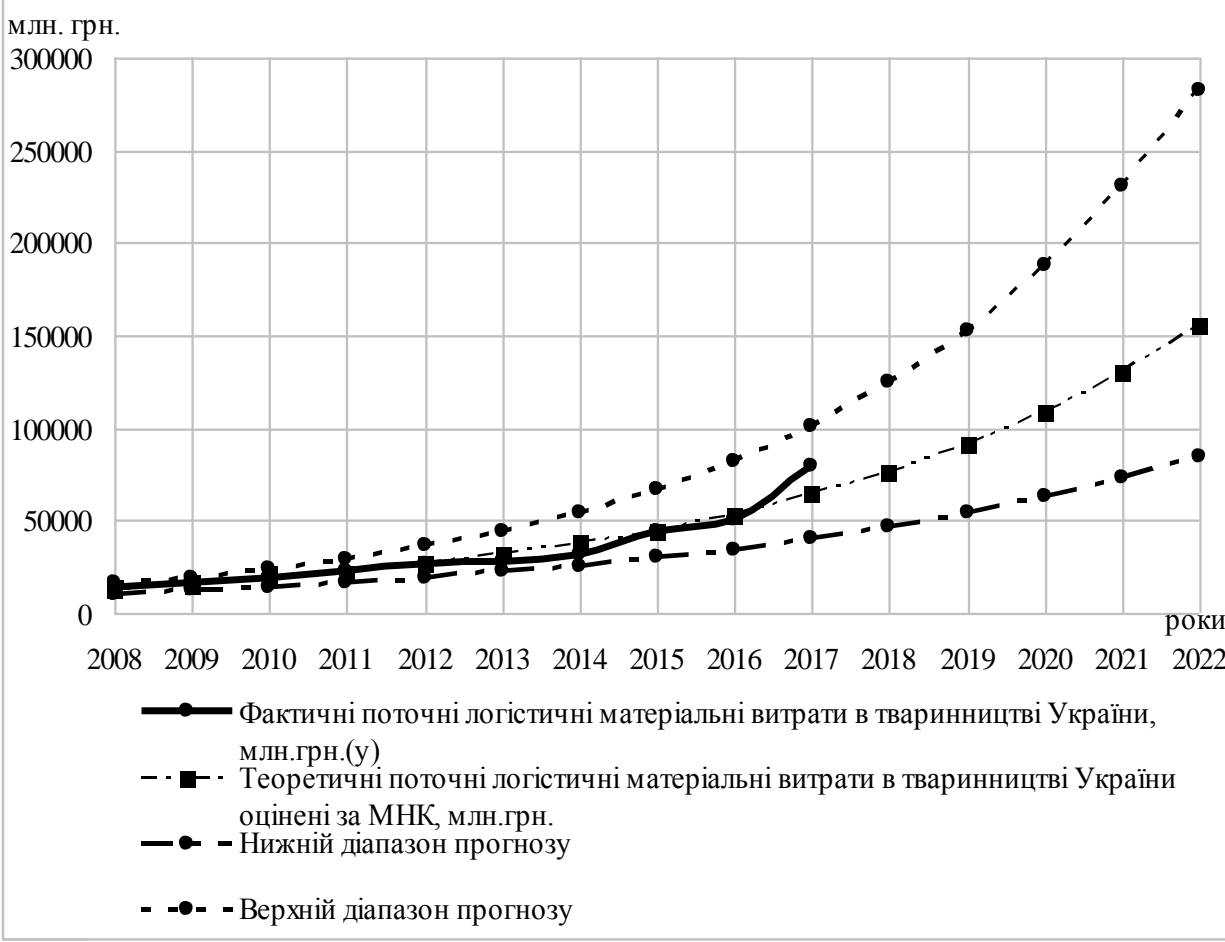

Рис. 3. Прогнозування поточних логістичних матеріальних витрат в тваринництві України, 2008 - 2022 рр., млн. грн.

Джерело: розроблено автором за даними [13]

Зростання поточних логістичних матеріальних витрат в сільському господарстві України підтверджується аналізом змін початкового та останнього рівнів динаміки. Порівняльні характеристики показників приросту поточних логістичних матеріальних витрат в сільському господарстві України наведено у таблиці 4. За розрахунками середнє зростання витрат в цілому по сільському господарству України в період з 2008 - 2017 рр. складало 20269,4 млн. грн. (121,3\% росту). При цьому коливання навколо середнього очікуваного рівня витрат становило 56,5\%, що свідчить про значний підвищений ризик понесених витрат. За прогнозними розрахунками в період з 2018 - 2022 рр. коливання навколо середнього очікуваного рівня витрат становитиме 27,6\%. Середній приріст буде на рівні 79130,9 млн. грн. (121,8\% росту). Тобто, прогнозується збільшення росту витрат на $0,5 \%$.

Середнє зростання поточних логістичних матеріальних витрат в рослинництві України в період з 2008 - 2017 рр. складало 12920,3 млн. грн. (120,9\% росту). При цьому коливання навколо середнього очікуваного рівня витрат становило $57,1 \%$.

Табличя 4

Показники приросту поточних логістичних матеріальних витрат в сільському господарстві України, 2008 - 2022 рр.

\begin{tabular}{|l|c|c|c|}
\hline \multicolumn{1}{|c|}{ Галузь } & $\begin{array}{c}\text { Середній абсолютний } \\
\text { приріст, млн. грн. }\end{array}$ & $\begin{array}{c}\text { Середній } \\
\text { коефіціснт росту, } \\
\text { \% }\end{array}$ & $\begin{array}{c}\text { Коефіціснт } \\
\text { варіації, } \\
\text { \% }\end{array}$ \\
\hline \multicolumn{2}{|c|}{ Фактичний рівень росту поточних логістичних матеріальних витрат, 2008-2017 pp. } \\
\hline Сільське господарство України & 20269,4 & 121,3 & 56,5 \\
\hline Рослинництво & 12920,3 & 120,9 & 57,1 \\
\hline Тваринництво & 7349,1 & 121,9 & 57,5 \\
\hline Прогнозований рівень росту поточних логістичних матеріальних витрат, 2018 - 2022 pp. \\
\hline Сільське господарство України & 79130,9 & 121,8 & 27,6 \\
\hline Рослинництво & 60130,8 & 122,9 & 28,9 \\
\hline Тваринництво & 19663,6 & 119,4 & 24,9 \\
\hline
\end{tabular}

Джерело: складено та розраховано автором на основі [13] 


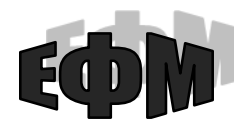

http://efm.vsau.org/

За прогнозними розрахунками в період з 2018 - $2022 \mathrm{pp}$. коливання навколо середнього очікуваного рівня витрат становитиме $28,9 \%$. Середній приріст буде на рівні 60130,8 млн. грн. (122,9\% росту). Прогнозується збільшення росту витрат на 2,0\%. Середнє зростання поточних логістичних матеріальних витрат в тваринництві в період з $2008-2017$ рр. складало 7349,1 млн. грн. (121,9\% росту). При цьому коливання навколо середнього очікуваного рівня витрат становило 57,5\%. В період з 2018 - $2022 \mathrm{pp}$. прогнозоване коливання навколо середнього очікуваного рівня витрат становитиме 24,9\%. Середній приріст становитиме 19663,6 млн. грн. (119,4\% росту). Прогнозується зменшення росту витрат на 2,5\%.

Висновок. Прогнозування та оцінка логістичних витрат є складним процесом, що в багатьох випадках залежить від суб'єктивізму прийняття управлінських рішень. Проблемним питанням залишається співвідношення логістичних витрат зі статтями бухгалтерського обліку. Проте в частині управлінського обліку актуальним залишається питання прогнозування та розробки бізнесмоделі. Прогнозування витрат в логістичних процесах є одним із ключових елементів моделі управління витратами, яка будується виходячи із таких складових, як: технологія використання ресурсів відносно логістичних функцій; механізм управління будується на засадах системного підходу та цільових принципів в прийнятті управлінських рішень; реалізація процесів відбувається шляхом запровадження управлінських функцій (прогнозування, планування, координація, регулювання, адміністрування, облік, моніторинг).

Для прогнозування поточних логістичних матеріальних витрат автором отримано регресійні оцінки за експоненціальною регресією, значимість яких підтверджена t-критерієм Cт'юдента та Fкритерієм Фішера. За прогнозною оцінкою середній рівень очікуваних логістичних матеріальних витрат в сільському господарстві України становить 406223,1 млн. грн., в т.ч. по рослинництву 295114,8 млн. грн. і по тваринництву - 112001,8 млн. грн. Очікувана динаміка змін витрат має низький рівень еластичності, який не перевищує $0,21 \%$ середньорічного росту. Найбільші темпи росту витрат характерні для галузі рослинництва, найменші - галузі тваринництва.

\section{Список використаних джерел:}

1. Кузнецова Т.В. Логистические затраты: экономическое содержание, состав, типология. Экономика и управление. 2012. № 3. С. 29 - 34.

2. Касьян Л.Е., Свіщов М.В. Аналіз впливу логістичних витрат на ефективність функціонування логістичної системи. Вісник Київського національного університету технологій та дизайну. 2013. №2. С. 150 - 155.

3. Васелевський М., Крикавський $€$. В. Інтеграція цілей в ланцюгу поставок промислової продукції. Вісник Хмельницького національного університету. 2011. № 6. Т. 2. С. 177-182.

4. Howard T. Lewis, James W. Culleton, and Jack D. Steel. The Role of Air Freight in Physical Distribution. Boston. Division of Research, Graduate School of Business Administration. Harvard University, 1956.

5. Крикавський Є. В., Якимишин Л. Я. Комплементарність стратегій маркетингу та логістики в ланцюгу поставок товарів повсякденного попиту. Маркетинг і цифррові технологіï. 2018. № 1. Том 2. С. 21-32.

6. Сумець О. М. Логістичні витрати підприємств олійно-жирової галузі: формування та оцінювання: монографія. Харків: Вид-во НУА, 2017. 243 с.

7. Шутько Т. І. Особливості формування витрат сільськогосподарських підприємств. Інвестииї: практика та досвід. 2015. № 22. С. 125-128.

8. Братухина Е. А. Влияние логистических издержек на себестоимость продукции предприятий по производству промышленного оборудования. Научно-методический электронный журнал "Концепт". 2014. T. 20. С. 2201 - 2205. URL: http://e-koncept.ru/2014/54704.htm.

9. Казарина Л.А. Логистические издержки: проблемы учета и оценки. Вестник ТГПУ. Серия: гуманитарные науки (экономика, право). 2007. Выпуск 9 (72). С. 24-27.

10.Боргардт Е.А., Дубровина А.С. Современные подходы к классификации логистических издержек. Проблемы экономики и менеджмента. 2015. № 7 (47). С. 3 - 8.

11.Яхнеева И. В. Прогнозирование логистических процессов в условиях неопределенности. Российское предпринимательство. 2013. № 9 (231). С. 118 - 125.

12. Лук'яненко І.Г., Краснікова Л.І. Економетрика: підручник. К.: Тов. “Знання” КОО, 1998. 368 с.

13.Офіційний сайт Державної служби статистики України. URL: http://ukrstat.gov.ua/.

14.Потапова Н.А., Павленко С.С. Прогнозування обсягів реалізації зернових культур в агрологістичних ланцюгах України. Збірник наукових праџь Таврійського державного агротехнологічного університету (економічні науки). 2014. №2(26). С. 157-164. 


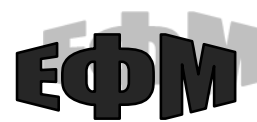

http://efm.vsau.org/

15. Волонтир Л.О. Інформаційне забезпечення прогнозування розвитку галузі буряківництва. Економіка. Фінанси. Менеджмент: актуальні питання науки і практики. 2019. №1. С. 71-82.

\section{References}

1. Kuznetsova, T.V. (2012) Logisticheskie zatratyi: ekonomicheskoe soderzhanie, sostav, tipologiya [Logistics costs: economic content, composition, typology]. Ekonomika $i$ upravlenie Economics and management, 3, 29-34 [in Russia].

2. Kasian, L.E. \& Svishchov, M.V. (2013) Analiz vplyvu lohistychnykh vytrat na efektyvnist funktsionuvannia lohistychnoi systemy [Analysis of the impact of logistics costs on the efficiency of the logistics system]. Visnyk Kyivskoho natsionalnoho universytetu tekhnolohii ta dyzainu - Bulletin of Kyiv national University of technology and design, 2, 150-155 [in Ukrainian].

3. Vaselevskyi, M. \& Krykavskyi, Ye. (2011) Intehratsiia tsilei v lantsiuhu postavok promyslovoi produktsii [Integration of objectives in the supply chain of industrial products]. Visnyk Khmelnytskoho natsionalnoho universytetu - Bulletin of Khmelnitsky national University, 6, 177-182 [in Ukrainian].

4. Howard T. Lewis, James W. Culleton, and Jack D. Steel. The Role of Air Freight in Physical Distribution. Boston. Division of Research, Graduate School of Business Administration. Harvard University, 1956.

5. Krykavskyi, Ye.V. \& Yakymyshyn, L. Ya. (2018) Komplementarnist stratehii marketynhu ta lohistyky v lantsiuhu postavok tovariv povsiakdennoho popytu [Complementarity of marketing and logistics strategies in the supply chain of goods of daily demand]. Marketynh i tsyfrovi tekhnolohii Marketing and digital technologies, 1, 21-32 [in Ukrainian].

6. Sumets, O. M. (2017) Lohistychni vytraty pidpryiemstv oliino-zhyrovoi haluzi: formuvannia ta otsiniuvannia: monohrafiia [Logistic expenses of oil and fat industry enterprises: formation and evaluation: monograph]. Kharkiv: vydavnytstvo narodna ukrainska akademiia - Kharkov: publishing house people's Ukrainian Academy, 243 [in Ukrainian].

7. Shutko, T. I. (2015) Osoblyvosti formuvannia vytrat silskohospodarskykh pidpryiemstv [Features of formation of costs of agricultural enterprises]. Investytsii: praktyka ta dosvid - Investment: practice and experience, 22, 125-128 [in Ukrainian].

8. Bratuhina, E. A. (2014) Vliyanie logisticheskih izderzhek na sebestoimost produktsii predpriyatiy po proizvodstvu promyishlennogo oborudovaniya [The Influence of logistics costs on the cost of production of enterprises for the production of industrial equipment]. Nauchno-metodicheskiy elektronnyiy zhurnal "Kontsept" - Scientific and methodical electronic journal "Concept", 20, 2201-2205. Retrieved from http://e-koncept.ru/2014/54704.htm.

9. Kazarina, L.A. (2007) Logisticheskie izderzhki: problemyi ucheta i otsenki. [Logistics costs: problems of accounting and evaluation]. Vestnik TGPU. Seriya: gumanitarnyie nauki (ekonomika, pravo) - Bulletin of TSPU. Series: Humanities (economics, law), 9(72), 24-27 [in Russia].

10.Borgardt, E.A. \& Dubrovina, A.S. (2015) Sovremennyie podhodyi k klassifikatsii logisticheskih izderzhek [Modern approaches to the classification of logistics costs]. Problemyi ekonomiki $i$ menedzhmenta - Problems of Economics and management, 7(47), 3-8 [in Russia].

11. Yahneeva, I.V. (2013) Prognozirovanie logisticheskih protsessov v usloviyah neopredelennosti [Forecasting of logistic processes under uncertainty]. Rossiyskoe predprinimatelstvo - Russian business, 9(231), 118-125 [in Russia].

12.Luk'ianenko, I.H. \& Krasnikova, L.I. (1998) Ekonometryka: pidruchnyk [Econometrics: pidruchnik]. Kyiv: Tov. "Znannia" KOO - Kyiv: Tov. "Knowledge" of KOO, 368 [in Ukrainian].

13.Ofitsiinyi sait Derzhavnoi sluzhby statystyky Ukrainy [Official website of the State statistics service of Ukraine]. www.ukrstat.gov.ua. Retrieved from http://ukrstat.gov.ua/ [in Ukrainian].

14.Potapova, N.A. \& Pavlenko, S.S. (2014) Prohnozuvannia obsiahiv realizatsii zernovykh kultur v ahrolohistychnykh lantsiuhakh Ukrainy [Forecasting of volumes of realization of grain crops in agrologistic chains of Ukraine]. Zbirnyk naukovykh prats Tavriiskoho derzhavnoho ahrotekhnolohichnoho universytetu (ekonomichni nauky) - Collection of scientific works of Taurida state agrotechnological University (Economics), 2(26). 157-164 [in Ukrainian].

15.Volontyr, L.O. (2019). Informatsiine zabezpechennia prohnozuvannia rozvytku haluzi buriakivnytstva. [Information support for forecasting the development of the beet industry] Ekonomika. Finansy. Menedzhment: aktual'ni pytannya nauky i praktyky - Economy. Finances. Management: topical issues of science and practice, 1, 71-82 [in Ukrainian]. 


\title{
Інформація про автора
}

http://efm.vsau.org/

ПОТАПОВА Надія Анатоліївна - кандидат економічних наук, доцент, доцент кафедри комп'ютерних наук та економічної кібернетики, Вінницький національний аграрний університет (21008, м. Вінниця, вул. Сонячна, 3, e-mail nauka.service@ gmail.com)

POTAPOVA Nadiya - candidate of economic sciences, associate professor, associate professor of computer science and economic cybernetics department, Vinnytsia National Agrarian University (21008, Vinnytsia Sonyachna St, 3, e-mail potapova.nadin@gmail.com)

ПОТАПОВА Надежда Анатольевна - кандидат экономических наук, доцент, доцент кафедры компьютерных наук и экономической кибернетики, Винницкий национальный аграрный университет (21008, г. Винница, ул. Солнечная, 3, e-mail potapova.nadin @ gmail.com)

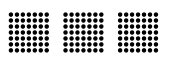

УАК: 338.18 .78

\author{
ЛОГІСТИЧНЕ ЗАБЕЗПЕЧЕННЯ РОЗВИТКУ \\ ЕКОНОМІКИ ЗА УМОВ ГЛОБАЛІЗАЦІї ${ }^{\odot}$
}

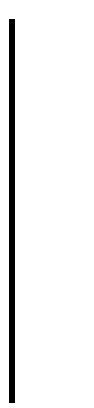

\author{
Л.М. КИШ, \\ кандидат економічних наук, доцент, \\ доцент кафедри моделювання \\ та інформаційних технологій \\ в економіці \\ Вінницький національний \\ аграрний університет \\ (м. Вінниця)
}

Досліджено роль логістичного забезпечення у розвитку економіки країни. Обтрунтовано, щчо управління логістичними потоками передбачає компонент управління ланцюгами поставок, який використовується для задоволення потреб клієнтів иляхом планування, контролю та впровадження ефективного переміщення та зберігання відповідної інформацї, товарів і послуг від місия походження до місия призначення. Виокремлено основні тенденції розвитку логістики в умовах глобалізаціі. Проаналізовано сучасний стан та динаміку обсягів перевезених вантажів в Украӥні за видами транспорту. Досліджено вплив експлуатащійної довжини иляхів сполучення загального користування на ефективність функціонування товарообігу у країні. Встановлено, щзо в сучасних умовах розвиток логістики характеризується декількома тенденціями, які мають суттєвий вплив на розвиток економіки: мінімізацією витрат, пов'язаних з транспортуванням, зберіганням, перепаковуванням; зростанням попиту на якісні логістичні послуги; зменшенням витрат виробників за рахунок оптимізації логістичних ланцююгів.

Ключові слова: логістика, економічний розвиток, глобалізація, інфраструктура, перевезення, транспорт, ефективність.

Табл.: 5. Рис.: 1. Літ.: 15.

\section{LOGISTIC PROVISION OF ECONOMIC DEVELOPMENT IN THE CONDITIONS OF GLOBALIZATION}

\author{
KYSH Liydmila, \\ Candidate of Economic Sciences, \\ Associate Professor of the Department of design and \\ Information technolog is in an economy, \\ Vinnytsia National Agrarian University \\ (Vinnytsia)
}

The role of logistic support in the development of the country's economy is explored. It is substantiated that logistics management involves a component of supply chain management that is used to meet the needs of customers through planning, controlling and implementing the efficient movement and 